Article

\title{
Predictive Binding Affinity of Plant-Derived Natural Products Towards the Protein Kinase G Enzyme of Mycobacterium tuberculosis (MtPknG)
}

\author{
Rana M. Qasaymeh ${ }^{1}$, Dino Rotondo ${ }^{1}$, Carel B. Oosthuizen ${ }^{2}{ }^{(1)}$, Namrita Lall ${ }^{2,3,4}$ and \\ Veronique Seidel ${ }^{1, *}$ \\ 1 Strathclyde Institute of Pharmacy and Biomedical Sciences, University of Strathclyde, Glasgow G4 0RE, UK; \\ rana-mohammad-mahmoud-qasaymeh@strath.ac.uk (R.M.Q.); d.rotondo@strath.ac.uk (D.R.) \\ 2 Department of Plant and Soil Sciences, University of Pretoria, Pretoria 0002, South Africa; \\ u04405765@tuks.co.za (C.B.O.); namrita.lall@up.ac.za (N.L.) \\ 3 School of Natural Resources, University of Missouri, Columbia, MO 65211, USA \\ 4 College of Pharmacy, JSS Academy of Higher Education and Research, Mysuru, Karnataka 570015, India \\ * Correspondence: veronique.seidel@strath.ac.uk; Tel.: +44-141-548-2751
}

Received: 10 October 2019; Accepted: 31 October 2019; Published: 6 November 2019

\begin{abstract}
Tuberculosis (TB), caused by Mycobacterium tuberculosis, is a growing public health concern worldwide, especially with the emerging challenge of drug resistance to the current drugs. Efforts to discover and develop novel, more effective, and safer anti-TB drugs are urgently needed. Products from natural sources, such as medicinal plants, have played an important role in traditional medicine and continue to provide some inspiring templates for the design of new drugs. Protein kinase $\mathrm{G}$, produced by $M$. tuberculosis ( $\mathrm{MtPKnG})$, is a serine/threonine kinase, that has been reported to prevent phagosome-lysosome fusion and help prolong $M$. tuberculosis survival within the host's macrophages. Here, we used an in silico, target-based approach (docking) to predict the interactions between MtPknG and 84 chemical constituents from two medicinal plants (Pelargonium reniforme and Pelargonium sidoides) that have a well-documented historical use as natural remedies for TB. Docking scores for ligands towards the target protein were calculated using AutoDock Vina as the predicted binding free energies. Ten flavonoids present in the aerial parts of P. reniforme and/or P. sidoides showed docking scores ranging from -11.1 to $-13.2 \mathrm{kcal} / \mathrm{mol}$. Upon calculation of all ligand efficiency indices, we observed that the $(-\Delta G / M W)$ ligand efficiency index for flavonoids (4), (5) and (7) was similar to the one obtained for the AX20017 control. When taking all compounds into account, we observed that the best $(-\Delta \mathrm{G} / \mathrm{MW})$ efficiency index was obtained for coumaric acid, coumaraldehyde, $p$-hydroxyphenyl acetic acid and $p$-hydroxybenzyl alcohol. We found that methyl gallate and myricetin had ligand efficiency indices superior and equal to the AX20017 control efficiency, respectively. It remains to be seen if any of the compounds screened in this study exert an effect in M. tuberculosis-infected macrophages.
\end{abstract}

Keywords: AutoDock Vina; flavonoids; molecular docking; Mycobacterium tuberculosis; Pelargonium reniforme; Pelargonium sidoides; Protein kinase G (PknG); SiteMap

\section{Introduction}

Tuberculosis (TB), an infectious disease which mainly affects the lungs and is caused by the bacterium Mycobacterium tuberculosis, has plagued humans since antiquity [1]. In 2017, the World Health Organisation estimated that there were 10 million TB cases worldwide, which resulted in a mortality rate of 1.6 million. The treatment of TB necessitates complex drug regimens, with adverse effects and interactions, and is associated with poor patient compliance. This has led to the evolution 
of multidrug-resistant (MDR-TB) and extensively drug-resistant (XDR-TB) strains. Patients with MDRor XDR-TB require a lengthy course of a combination of drugs that are more expensive, more toxic, and not always effective [2]. With the continuous increase in the number of drug-resistant TB cases, it is vital to identify drugs that could inhibit new druggable targets in M. tuberculosis [3-8]. Eleven different serine/threonine protein kinases have been reported in mycobacteria, including protein kinase $\mathrm{G}$ in M. tuberculosis (MtPknG), which is of particular interest, not only because it regulates the signal transduction pathways that control the metabolism of $M$. tuberculosis, but because it plays an essential role in promoting the survival and persistence of this pathogen within macrophages. MtPknG is a soluble enzyme, secreted by M. tuberculosis, that belongs to the family of prokaryotic Ser/Thr protein kinases (STPKs). The latter play an important function in the phosphorylation of proteins involved in signal transduction pathways that control a range of metabolic processes in bacteria. MtPknG is essential for sustaining TB infection, by promoting the survival and persistence of $M$. tuberculosis within infected macrophages through blocking phagosome-lysosome fusion. It has recently been identified as a key regulator in the mycobacterial metabolism of carbon and nitrogen. Additionally, it is required for the formation of mycobacterial biofilms and is involved in the development of anti-TB drug resistance in mycobacteria. Targeting MtPknG represents one possible approach for the discovery of new anti-TB drugs [9-23].

Products of natural origin contain a unique pool of incredibly chemically diverse molecules that have specifically evolved to interact with biological targets and have already provided some invaluable leads for drug design [24]. Plant-based medicines, in particular, are used widely by traditional healers in different parts of the world, including for the treatment of TB and TB-related symptoms [25-28]. Many plant extracts and plant-derived chemicals have demonstrated antitubercular activity [29-32]. Pelargonium sidoides DC. and Pelargonium reniforme Curtis (Geraniaceae) are two plants indigenous to South Africa that are used as natural remedies for wound-healing (aerial parts), as well as for gastrointestinal disorders, persistent coughs and respiratory tract infections, including TB (roots) [33,34]. A tincture made from P. sidoides and P. reniforme roots, known as "Umckaloabo", was introduced into Europe in the early 20th century by the Englishman Charles Stevens, who claimed to have recovered from TB after taking "Umckaloabo". The remedy, known as "Stevens' Consumption Cure", was subsequently used in Europe to treat more than $800 \mathrm{~TB}$ patients and is currently licensed for the treatment of upper respiratory tract infections [34-39]. The exact nature and mechanism of action of the substance(s) responsible for the effect observed in TB cases have yet to be fully understood.

Molecular docking is an in silico, target-based approach used in the virtual screening of small molecules (ligands) against a given protein (target) [40], that has already been applied to the search for new anti-TB drugs from natural sources [41,42]. Here, we report on the use of a guided docking approach, using AutoDock Vina, to predict the interactions between some natural products from the roots/aerial parts of P. reniforme/P. sidoides and MtPknG, as a starting point in the search for new anti-TB agents.

\section{Results}

A total of eighty-four natural products from the aerial parts and roots of both Pelargonium spp. were selected for our molecular docking study. They were grouped into four categories, namely phenolics, coumarins (comprising coumarin glycosides and coumarin sulfates), flavonoids, and other miscellaneous compounds. The tetrahydrobenzothiophene derivative AX20017, a known inhibitor of the target enzyme, was retrieved from its co-crystallised complex with $M t P k n G$, and re-docked as a control against the enzyme to validate the docking conditions [43]. The binding site of the co-crystallised inhibitor was identified as the most favourable docking site, with a higher site score and druggability score (1.138 and 1.174, respectively) when compared to the other potential binding sites (1.027 and 1.034) (Table 1). Knowing the nature of the key amino acid residues involved in the binding [43], we employed a rigid ligand docking approach to predict the affinity of each natural product from Pelargonium towards MtPknG. The docking scores obtained using Auto Dock Vina ranged 
between -5.8 and $-13.2 \mathrm{kcal} / \mathrm{mol}$. The docking score for the AX20017 control was $-7.9 \mathrm{kcal} / \mathrm{mol}$ (RMSD to input ligand $=0.5476 \AA$ ) (Table S1). Ten flavonoids present in the aerial parts of $P$. reniforme and/or P. sidoides showed docking scores ranging from -11.1 to $-13.2 \mathrm{kcal} / \mathrm{mol}$ (Table 2). Ligand efficiency indices were calculated for all ligands and are presented in Table 2 and Table S1.

Table 1. Identified binding sites for MtPknG using SiteMap.

\begin{tabular}{|c|c|c|c|}
\hline Binding Site & SiteScore $^{1}$ & DScore $^{2}$ & Volume ( $\mathrm{A})$ \\
\hline 1 (AX20017-Co-crystallised site) & 1.138 & 1.174 & 271.31 \\
\hline 2 & 1.027 & 1.034 & 1548.65 \\
\hline 3 & 1.012 & 1.067 & 270.97 \\
\hline 4 & 0.950 & 0.971 & 301.84 \\
\hline 5 & 0.940 & 0.968 & 498.38 \\
\hline
\end{tabular}

${ }^{1}$ Quality of the identified binding site (SiteScore $\left.=0.0733 \operatorname{sqrt}(\mathrm{n})+0.6688 \mathrm{e}-0.20 \mathrm{p}\right) .{ }^{2}$ Druggability score.

Table 2. Origin of Pelargonium natural products (1-10), and their predicted free binding energy (docking score $\Delta \mathrm{G}$ in $\mathrm{kcal} / \mathrm{mol}$ ) and ligand efficiency indices towards $M t \mathrm{PknG}^{\mathrm{a}}$.

\begin{tabular}{ccccccc}
\hline Compound & P. reniforme & P. sidoides & Docking Score & \multicolumn{2}{c}{ Ligand Efficiency Indices } \\
\hline & & & & LE1 & LE2 & LE3 \\
\hline Isoorientin 2"-O-gallate (1) & AP & AP & -13.2 & 0.31 & 0.47 & 0.02 \\
Isovitexin 2"-O-gallate (2) & & AP & -12.6 & 0.30 & 0.45 & 0.02 \\
Nicotiflorin (3) & AP & & -12.2 & 0.29 & 0.45 & 0.02 \\
Orientin (4) & AP & AP & -11.8 & 0.37 & 0.56 & 0.03 \\
Populnin (5) & AP & & -11.6 & 0.36 & 0.55 & 0.03 \\
Rutin (6) & AP & & -11.4 & 0.27 & 0.42 & 0.02 \\
Vitexin (7) & AP & AP & -11.2 & 0.36 & 0.53 & 0.03 \\
Quercimeritrin (8) & AP & & -11.2 & 0.34 & 0.53 & 0.02 \\
Isoorientin (9) & AP & AP & -11.2 & 0.35 & 0.53 & 0.02 \\
Glucoluteolin (10) & & AP & -11.1 & 0.35 & 0.53 & 0.02 \\
\hline
\end{tabular}

$\mathrm{AP}=$ Aerial parts; $\mathrm{R}=$ Roots. LE1 defines the ligand efficiency coefficient calculated as- $(\Delta \mathrm{G} /$ number of heavy atoms in the ligand). LE2 defines the ligand efficiency coefficient calculated as-( $\Delta \mathrm{G} /$ number of carbons in the ligand). LE3 defines the ligand efficiency coefficient calculated as- $\left(\Delta \mathrm{G} / \mathrm{molecular}\right.$ weight of the ligand). ${ }^{\text {a }}$ The re-docked AX20017 control inhibitor had a docking score of $-7.9 \mathrm{kcal} / \mathrm{mol}$ against $M t P \mathrm{knG}$ and ligand efficiencies of LE1, LE2 and LE3 of 0.44, 0.61 and 0.03, respectively.

The nature of the intermolecular interactions formed with the amino acid residues of $M t P \mathrm{knG}$ were further investigated for the five flavonoid ligands showing the strongest docking scores, namely isoorientin 2" -O-gallate (1), isovitexin 2"-O-gallate (2), nicotiflorin (3), orientin (4) and populnin (5) (Figure 1) (Table 3). A closer look at the interactions between isoorientin $2^{\prime \prime}$-O-gallate (1) and MtPknG revealed that the sugar moiety of this flavonoid was bound via strong hydrogen bonds to Ser239 and Lys241, while the para-hydroxyl group of the gallate unit was bound to His159. This specific hydrogen-bonding network enabled the flavone backbone of (1) to be positioned in such a way as to develop further hydrophobic interactions with Ala158, Val179 and Ile292 (Figure 2a,b). In the case of isovitexin 2"-O-gallate (2), the gallate unit and the para-hydroxyl on the B ring of the flavonoid formed hydrogen bonds with Lys241 and Met232 (2.168 and $2.903 \AA$, respectively). Hydrophobic interactions were also present between (2) and Ala158, Val179, Val235 and Ile292 (Figure 3a,b). Nicotiflorin (3) showed numerous interactions with $M t P k n G$, including strong hydrogen bonds (contact distances $<2.5 \AA$ ) with Glu233, Glu280, Gln238 and Ser 239 (Figure S1a). The B-ring hydroxyl groups of orientin (4) showed three hydrogen bonds with Lys181, and one with Asp293, while the flavone backbone interacted via hydrophobic interactions with Ala158 and Ile157 (Figure S2a). Populnin (5) also interacted strongly through hydrogen bonds with Lys181, Asp 293 and Gln238 (2.498, 2.213 and $2.278 \AA$, respectively) and via hydrophobic interactions with Ala158, Ile157, Ile165, Ile292 and Met283 (Figure S3a). An overlay of the docked poses of the control inhibitor AX20017, isoorientin 2"-O-gallate (1) and isovitexin 2"-O-gallate (2) in the MtPknG binding site is presented in Figure S4. 


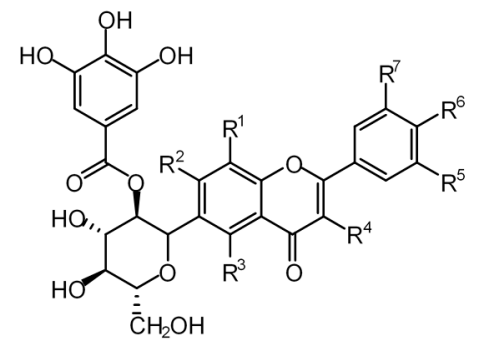

1 (Isoorientin2"-O-gallate) $R^{1}=R^{4}=R^{7}=H, R^{2}=R^{3}=R^{5}=R^{6}=O H$

2 (Isovitexin2"-O-gallate) $R^{1}=R^{4}=R^{5}=R^{7}=H, R^{2}=R^{3}=R^{6}=O H$<smiles>CC1O[C@H](CO[C@H]2O[C@H](Oc3c(-c4ccc(O)cc4)oc4cc(O)cc(O)c4c3=O)C(O)[C@@H](O)[C@H]2O)[C@H](O)[C@H](O)[C@H]1O</smiles>

3 (Nicotiflorin)<smiles>O=c1cc(-c2ccc(O)c(O)c2)oc2c([C@H]3O[C@H](CO)[C@@H](O)[C@H](O)[C@H]3O)c(O)cc(O)c12</smiles>

4 (Orientin)<smiles>O=c1c(O)c(-c2ccc(O)cc2)oc2cc(O[C@@H]3O[C@H](CO)[C@@H](O)[C@H](O)C3O)cc(O)c12</smiles>

5 (Populnin)

Figure 1. Structures of Pelargonium flavonoids (1-5).

Table 3. Detailed molecular interactions obtained following the rigid ligand docking of Pelargonium compounds (1) to (5), with MtPknG.

\begin{tabular}{|c|c|c|c|c|}
\hline Ligand & $\begin{array}{c}\text { Interacting } \\
\text { Residues }\end{array}$ & Distance (̊̊) & Category & Type \\
\hline \multirow[t]{8}{*}{ Isoorientin $2^{\prime \prime}$-O-gallate (1) } & Lys241 & 2.650 & H-Bond & Conventional \\
\hline & Ser239 & 2.825 & H-Bond & Conventional \\
\hline & His159 & 3.063 & H-Bond & Conventional \\
\hline & Lys241 & 3.140 & H-Bond & Carbon Hydrogen Bond \\
\hline & Ser239 & 3.512 & H-Bond & Carbon Hydrogen Bond \\
\hline & Ile292 & 4.701 & Hydrophobic & Pi-Alkyl \\
\hline & Val179 & 4.893 & Hydrophobic & Pi-Alkyl \\
\hline & Ala158 & 4.195 & Hydrophobic & Pi-Alkyl \\
\hline \multirow[t]{6}{*}{ Isovitexin $2^{\prime \prime}$-O-gallate (2) } & Lys241 & 2.168 & H-Bond & Conventional \\
\hline & Met232 & 2.903 & H-Bond & Conventional \\
\hline & Ala158 & 3.898 & Hydrophobic & Pi-Sigma \\
\hline & Ile292 & 4.811 & Hydrophobic & Pi-Alkyl \\
\hline & Val235 & 5.002 & Hydrophobic & Pi-Alkyl \\
\hline & Val179 & 4.317 & Hydrophobic & Pi-Alkyl \\
\hline \multirow[t]{14}{*}{ Nicotiflorin (3) } & Glu233 & 2.134 & H-Bond & Conventional \\
\hline & Glu280 & 2.286 & H-Bond & Conventional \\
\hline & $\mathrm{G} \ln 238$ & 2.290 & H-Bond & Conventional \\
\hline & Ser239 & 2.357 & H-Bond & Conventional \\
\hline & Ile86 & 5.025 & Hydrophobic & Alkyl \\
\hline & Ile292 & 3.768 & Hydrophobic & Pi-Sigma \\
\hline & Ile292 & 3.898 & Hydrophobic & Pi-Sigma \\
\hline & Ile157 & 4.605 & Hydrophobic & Pi-Alkyl \\
\hline & Ala91 & 4.608 & Hydrophobic & Pi-Alkyl \\
\hline & Ala158 & 4.846 & Hydrophobic & Pi-Alkyl \\
\hline & Ala158 & 5.218 & Hydrophobic & Pi-Alkyl \\
\hline & Ile165 & 5.290 & Hydrophobic & Pi-Alkyl \\
\hline & Met283 & 5.468 & Hydrophobic & Pi-Alkyl \\
\hline & Val235 & 5.471 & Hydrophobic & Pi-Alkyl \\
\hline \multirow[t]{4}{*}{ Orientin (4) } & Lys181 & 2.248 & H-Bond & Conventional \\
\hline & Lys181 & 2.715 & H-Bond & Conventional \\
\hline & Lys181 & 2.669 & H-Bond & Conventional \\
\hline & Asp293 & 2.728 & H-Bond & Conventional \\
\hline
\end{tabular}


Table 3. Cont.

\begin{tabular}{ccccc}
\hline Ligand & $\begin{array}{c}\text { Interacting } \\
\text { Residues }\end{array}$ & Distance (Å) & Category & Type \\
\hline & Ala158 & 4.835 & Hydrophobic & Pi-Alkyl \\
Ala158 & 4.453 & Hydrophobic & Pi-Alkyl \\
& Ile157 & 4.846 & Hydrophobic & Pi-Alkyl \\
\hline Populnin (5) & Asp293 & 2.213 & H-Bond & Conventional \\
& Gln238 & 2.278 & H-Bond & Conventional \\
& Lys181 & 2.498 & H-Bond & Conventional \\
Gln238 & 3.455 & H-Bond & Carbon Hydrogen Bond \\
& Ile292 & 3.872 & Hydrophobic & Pi-Sigma \\
Ala158 & 4.526 & Hydrophobic & Pi-Alkyl \\
Ala158 & 4.714 & Hydrophobic & Pi-Alkyl \\
& Ile165 & 4.817 & Hydrophobic & Pi-Alkyl \\
& Met283 & 5.127 & Hydrophobic & Pi-Alkyl \\
& Ile165 & 5.150 & Hydrophobic & Pi-Alkyl \\
& Ile292 & 5.159 & Hydrophobic & Pi-Alkyl \\
& Ile157 & 5.311 & Hydrophobic & Pi-Alkyl \\
\hline
\end{tabular}

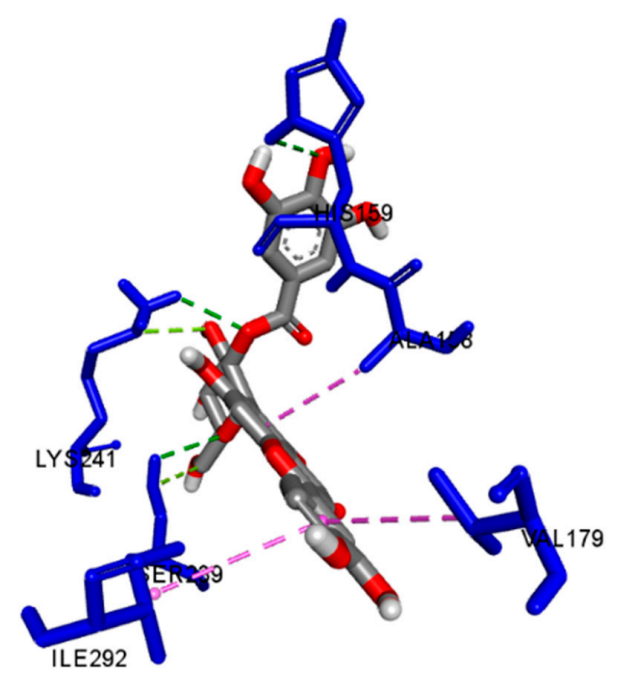

(a)

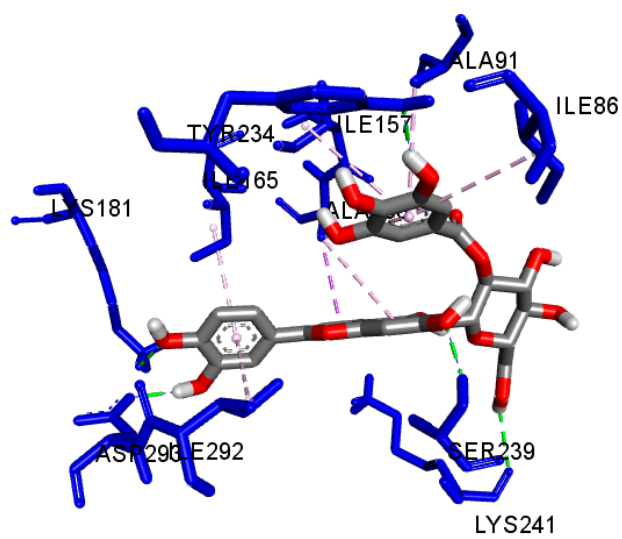

Interactions

$\square$ van der Waals

Conventional Hydrogen

(c)

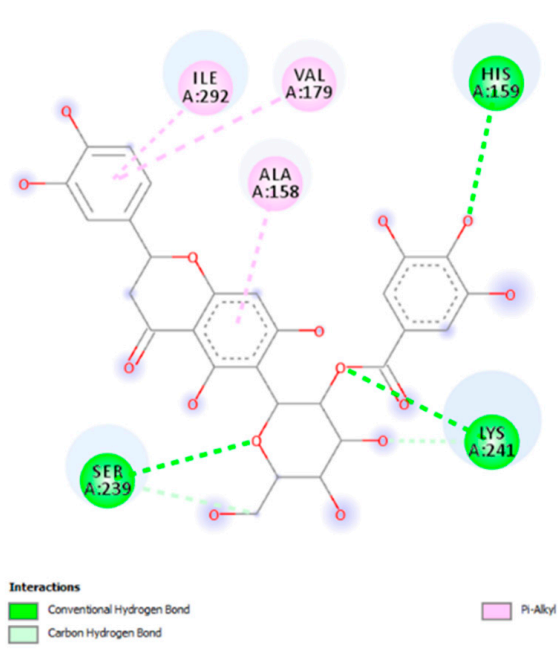

(b)

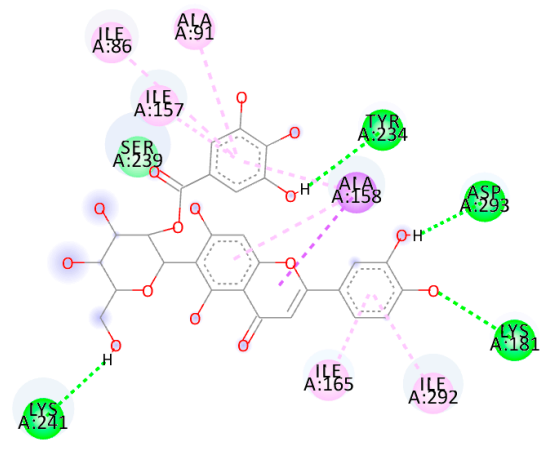

Pi-Sigma

(d)

Figure 2. (a) Docked pose of rigid isoorientin $2^{\prime \prime}-O$-gallate (1) in the $M t P k n G$ binding site, showing molecular interactions-hydrogen and hydrophobic bonds as green and pink/purple dashed lines, respectively; (b) 2D plot of interactions between (1) and key residues MtPknG generated by BIOVIA 
Discovery Studio visualizer. The solvent accessible surface is depicted as a background grey circle with the radius proportional to the exposure. (c) Docked pose of flexible isoorientin $2^{\prime \prime}$-O-gallate (1) in the $M t P k n G$ binding site showing molecular interactions-hydrogen and hydrophobic bonds as green and pink/purple dashed lines, respectively; (d) 2D plot of interactions between (1) and key residues of $M t P k n G$ generated by BIOVIA Discovery Studio visualizer. The solvent accessible surface is depicted as a background grey circle with the radius proportional to the exposure.

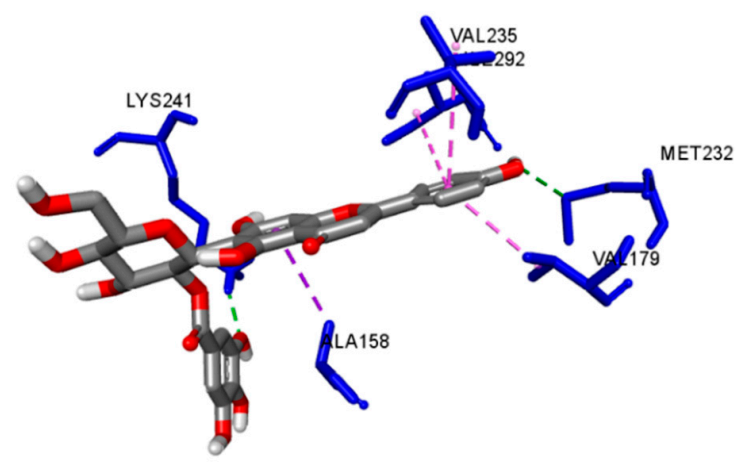

(a)

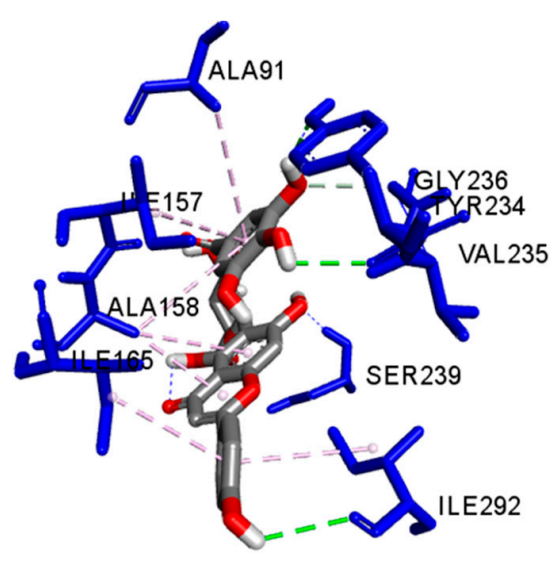

(c)

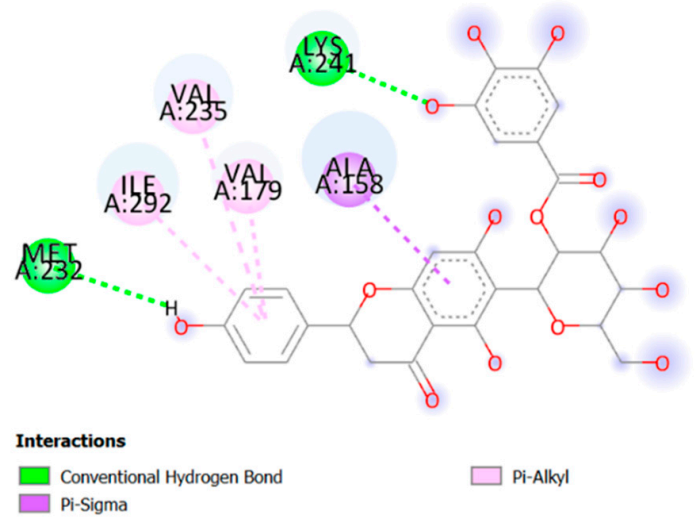

(b)

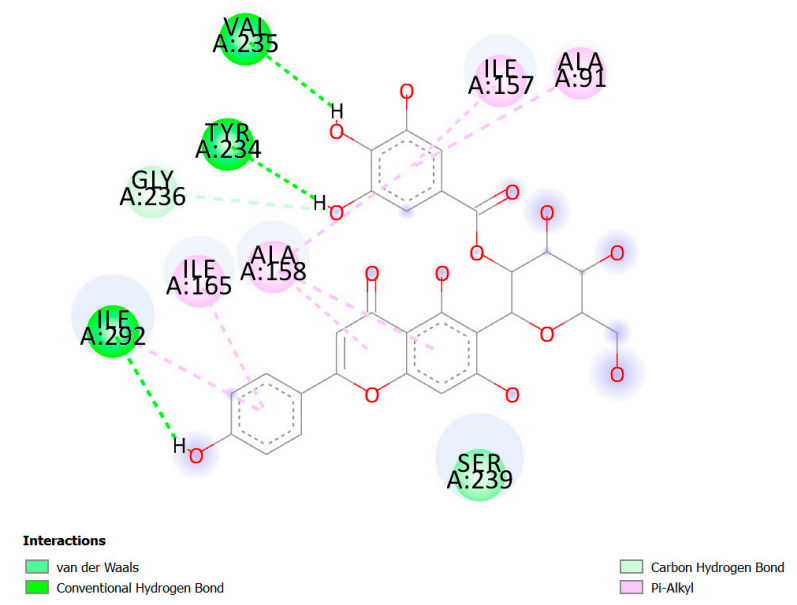

(d)

Figure 3. (a) Docked pose of rigid isovitexin 2"-O-gallate (2) in the MtPknG binding site, showing molecular interactions-hydrogen and hydrophobic bonds as green and pink/purple dashed lines, respectively; (b) 2D plot of interactions between (2) and key residues of $M t P k n G$ generated by BIOVIA Discovery Studio visualizer. The solvent accessible surface is depicted as a background grey circle with the radius proportional to the exposure. (c) Docked pose of flexible isovitexin 2"-O-gallate (2) in the $M t P k n G$ binding site showing molecular interactions-hydrogen and hydrophobic bonds as green and pink/purple dashed lines, respectively; (d) 2D plot of interactions between (2) and key residues of $M t P k n G$ generated by BIOVIA Discovery Studio visualizer. The solvent accessible surface is depicted as a background grey circle with the radius proportional to the exposure.

Owing to the presence of several rotatable bonds in the five aforementioned flavonoids, a flexible ligand docking approach was further employed, to identify differences between poses obtained by flexible and rigid docking (Table 4). Specific molecular interactions between $M t P k n G$ and isoorientin 
2"-O-gallate (1), isovitexin 2" -O-gallate (2), nicotiflorin (3), orientin (4) and populnin (5) are depicted in Figure 2c,d, Figure 3c,d, Figures S1b, S2b, and S3b, respectively.

Table 4. Detailed molecular interactions obtained following the flexible ligand docking of Pelargonium compounds (1) to (5), with MtPknG.

\begin{tabular}{|c|c|c|c|c|}
\hline Ligand & $\begin{array}{c}\text { Interacting } \\
\text { Residues }\end{array}$ & Distance (Å) & Category & Type \\
\hline \multirow[t]{13}{*}{ Isoorientin $2^{\prime \prime}$-O-gallate (1) } & Lys181 & 2.583 & H-Bond & Conventional \\
\hline & Lys241 & 2.657 & H-Bond & Conventional \\
\hline & Ser239 & 2.086 & H-Bond & Conventional \\
\hline & Tyr234 & 2.022 & H-Bond & Conventional \\
\hline & Asp293 & 1.867 & H-Bond & Conventional \\
\hline & Ile 86 & 5.361 & Hydrophobic & Pi-Alkyl \\
\hline & Ala158 & 3.929 & Hydrophobic & Pi-Sigma \\
\hline & Ile292 & 5.263 & Hydrophobic & Pi-Alkyl \\
\hline & Ala91 & 4.738 & Hydrophobic & Pi-Alkyl \\
\hline & Ile165 & 4.592 & Hydrophobic & Pi-Alkyl \\
\hline & Ala158 & 4.984 & Hydrophobic & Pi-Alkyl \\
\hline & Ile157 & 5.154 & Hydrophobic & Pi-Alkyl \\
\hline & Ala158 & 5.213 & Hydrophobic & Pi-Alkyl \\
\hline \multirow[t]{12}{*}{ Isovitexin 2"-O-gallate (2) } & Ser239 & 2.184 & H-Bond & Conventional \\
\hline & Tyr234 & 2.241 & H-Bond & Conventional \\
\hline & Val235 & 2.699 & H-Bond & Conventional \\
\hline & Ile292 & 3.044 & H-Bond & Conventional \\
\hline & Gly236 & 3.376 & H-Bond & Carbon Hydrogen Bond \\
\hline & Ala158 & 3.914 & Hydrophobic & Pi-Alkyl \\
\hline & Ile292 & 4.878 & Hydrophobic & Pi-Alkyl \\
\hline & Ile165 & 4.373 & Hydrophobic & Pi-Alkyl \\
\hline & Ala158 & 4.793 & Hydrophobic & Pi-Alkyl \\
\hline & Ala91 & 4.847 & Hydrophobic & Pi-Alkyl \\
\hline & Ile157 & 5.105 & Hydrophobic & Pi-Alkyl \\
\hline & Ala158 & 5.089 & Hydrophobic & Pi-Alkyl \\
\hline \multirow{11}{*}{ Nicotiflorin (3) } & Lys181 & 3.005 & H-Bond & Conventional \\
\hline & Ser239 & 2.146 & H-Bond & Conventional \\
\hline & Asn281 & 2.163 & H-Bond & Conventional \\
\hline & Val235 & 2.174 & H-Bond & Conventional \\
\hline & Ile292 & 3.747 & Hydrophobic & Pi-Sigma \\
\hline & Ile86 & 4.966 & Hydrophobic & Alkyl \\
\hline & Val235 & 5.072 & Hydrophobic & Pi-Alkyl \\
\hline & Ile292 & 4.468 & Hydrophobic & Pi-Alkyl \\
\hline & Ala158 & 5.195 & Hydrophobic & Pi-Alkyl \\
\hline & Ile165 & 4.364 & Hydrophobic & Pi-Alkyl \\
\hline & Ile165 & 5.392 & Hydrophobic & Pi-Alkyl \\
\hline \multirow[t]{14}{*}{ Orientin (4) } & Ile157 & 2.477 & H-Bond & Conventional \\
\hline & Glu233 & 2.407 & H-Bond & Conventional \\
\hline & Val235 & 2.155 & H-Bond & Conventional \\
\hline & Val235 & 2.423 & H-Bond & Conventional \\
\hline & Gly237 & 2.227 & H-Bond & Conventional \\
\hline & Ser239 & 2.379 & H-Bond & Conventional \\
\hline & Glu280 & 2.411 & H-Bond & Conventional \\
\hline & Ala158 & 3.574 & Hydrophobic & Pi-Sigma \\
\hline & Ala158 & 3.885 & Hydrophobic & Pi-Alkyl \\
\hline & Ile165 & 4.567 & Hydrophobic & Pi-Alkyl \\
\hline & Ile165 & 5.400 & Hydrophobic & Pi-Alkyl \\
\hline & Val179 & 4.437 & Hydrophobic & Pi-Alkyl \\
\hline & Ile292 & 5.460 & Hydrophobic & Pi-Alkyl \\
\hline & Ile292 & 4.538 & Hydrophobic & Pi-Alkyl \\
\hline \multirow[t]{6}{*}{ Populnin (5) } & Gln238 & 2.130 & H-Bond & Conventional \\
\hline & Gln238 & 2.443 & H-Bond & Conventional \\
\hline & Ser239 & 2.297 & H-Bond & Conventional \\
\hline & Asn281 & 2.296 & H-Bond & Conventional \\
\hline & Lys181 & 2.699 & H-Bond & Conventional \\
\hline & Lys181 & 2.571 & H-Bond & Conventional \\
\hline
\end{tabular}


Table 4. Cont.

\begin{tabular}{ccccc}
\hline Ligand & $\begin{array}{c}\text { Interacting } \\
\text { Residues }\end{array}$ & Distance (Å) & Category & Type \\
\hline Ala158 & 4.391 & Hydrophobic & Pi-Alkyl \\
Ile165 & 5.080 & Hydrophobic & Pi-Alkyl \\
Ile292 & 5.175 & Hydrophobic & Pi-Alkyl \\
Ile157 & 4.571 & Hydrophobic & Pi-Alkyl \\
Ala158 & 4.148 & Hydrophobic & Pi-Alkyl \\
Ile165 & 4.783 & Hydrophobic & Pi-Alkyl \\
Ile292 & 5.122 & Hydrophobic & Pi-Alkyl \\
\hline
\end{tabular}

\section{Discussion}

$M t P k n G$ is a multidomain protein that comprises an $\mathrm{N}$-terminal rubredoxin-like domain (including two thioredoxin motifs), followed by a central kinase domain (containing the ATP-binding site) and, finally, a C-terminal tetratricopeptide-repeat domain. The N-terminal domain is crucial for the kinase activity of $M t P k n G$. The C-terminal domain acts as a regulator of such activity by stabilizing interactions with the substrates $[21,43,44]$. MtPknG shares a low sequence similarity with human STPKs and the binding pocket of its enzymatic active site contains a unique set of amino acid residues, that does not occur in any human kinase. This makes $M t P k n G$ an interesting target, that can be exploited in the development of novel selective inhibitors [16,17,43,44].

The tetrahydrobenzothiophene compound AX20017 interacts with the ATP binding pocket of MtPknG via a unique set of hydrophobic amino acids, comprising Ile165, Val179, Gly236 and Ile292 of the ATP-binding site, and Ile87 and Ala92 of the N-terminal region. Other interacting residues include Ala158, Lys181, Met232, Glu233, Val235 and Asp293 [11,43,45]. Other potential inhibitors of $M t P k n G$, identified through molecular docking screenings, and of natural origin, include withanolide derivatives from the ayurvedic medicinal plant Withania somnifera (L.) Dunal [46] and the marine-derived sclerotiorin $\left(\mathrm{IC}_{50}=76.5 \mu \mathrm{M}\right)$ [47]. These compounds have demonstrated interactions with Glu233 and Val235, Gly237, Gln238 and Ser239, Lys241, Ile292, Ser293, Ala158, Ile165, Val179, Lys181, Met232, Ile292, Asp293 [46], and with Gly161, Leu162 and Lys278, respectively [47].

As observed in the control inhibitor AX20017 and the withanolide derivatives, compound (1) interacted with key amino acid residues of the MtPknG active site, i.e., Lys 241, Ser239, Ala158 and Ile292, in both rigid and flexible docking. Also as observed in AX20017 and the withanolides, it displayed a further interaction with Val179 in rigid docking, whereas, in flexible docking, it interacted with Ile165 and Asp293. It also interacted with Lys181 (as for AX20017) in flexible docking. Compound (2) interacted with Ala158, Ile292 and Val235 in both rigid and flexible docking, similar to the control inhibitor and the withanolide derivatives. In rigid docking alone, it also interacted with Lys241, Val179 and Met232 (as did the control inhibitor and the withanolide derivatives). In flexible docking, it interacted with Ser239 (as did the withanolides), Gly236 (similar to AX20017), and Ile165 (similar to both the control and the withanolides). Compound (3) interacted with Ser239, Ile86, Ile292, Ala158, Ile165 and Val235 in both rigid and flexible docking, similar to AX20017 and the withanolide derivatives. In rigid docking alone, it also interacted with Glu233 (as did the control and the withanolides) and Gln238 (as did the withanolides). In flexible docking, it further interacted with Lys181. Compound (4) interacted with Ala158 and Ile157 in both rigid and flexible docking. In rigid docking alone, it also interacted with Lys181 and Asp293 (as did the control inhibitor and the withanolides). In flexible docking, more interactions were observed with Glu233, Val235, Ser239, Ile165, Val179 and Ile292. Compound (5) interacted with Gln238, Lys181, Ile292, Ala158, Ile165 and Ile157, in both rigid and flexible docking. In rigid docking alone, it also interacted with Asp293 (similar to the control inhibitor and the withanolides). In flexible docking, an additional interaction with Ser239 (as seen for the withanolides) was observed. Overall, the interactions observed in flexible ligand and in rigid ligand docking protocols showed good agreement with previously published data [43-46]. 
In order to adequately compare the efficiency of smaller size ligands with larger size ligands, three ligand efficiency indices were further calculated for all compounds. These included a ligand efficiency index (coded as LE3 in Table 2 and Table S1) calculated by dividing the predicted free energy of binding $(-\Delta \mathrm{G})$ by the molecular weight $(\mathrm{MW})$ for each compound [48]. We observed that this $(-\Delta G / M W)$ efficiency index for flavonoids (4), (5) and (7) was similar to the one obtained for the AX20017 control (LE3 $=0.03)$. When taking all compounds into account, we observed that the best $(-\Delta \mathrm{G} / \mathrm{MW})$ efficiency index was obtained for coumaric acid, coumaraldehyde, $p$-hydroxyphenyl acetic acid and $p$-hydroxybenzyl alcohol (LE3 $=0.05)$.

Previous studies on Pelargonium have revealed that extracts and constituents of P. sidoides/reniforme leaves possess moderate activity against Gram-positive and Gram-negative bacteria [49]. Extracts obtained from Pelargonium roots possess direct antimycobacterial activity, including activity against M. tuberculosis $[33,50]$. Some mixtures of long-chain fatty acids, active against rapidly growing mycobacteria, have been isolated from $P$. sidoides/reniforme root extracts, with linoleic acid identified as one of the active compounds [51]. Epigallocatechin and scopoletin, from P. sidoides roots, have exhibited activity against $M$. smegmatis [50]. The exact identity of the constituents responsible for the direct activity of $P$. sidoides/reniforme against M. tuberculosis, however, is less clear. No specific antitubercular constituent has so far been isolated from P. reniforme and, although a chemical analysis of a P. sidoides root extract, active on M. tuberculosis, found four coumarins (umckalin, scopoletin, 6,8-dihydroxy-5,7-dimethoxycoumarin, and 6,8-dihydroxy-7-methoxycoumarin) and two flavonoids (catechin and epigallocatechin), none of these compounds, when tested against $M$. tuberculosis and in M. tuberculosis-infected macrophages, have demonstrated any biological effects [50].

As early as 1930, it was suggested that the curative properties of both Pelargonium spp. in TB cases were likely to be caused by the stimulation of a macrophage-mediated killing of Mycobacterium [37]. Studies since then have reported that extracts and constituents of P. sidoides, in particular gallic acid and methyl gallate, could reduce the survival of the intracellular parasite Leishmania donovani, and this was attributed to the activation of some non-specific immune response mechanisms within macrophages [33,52,53]. A similar effect has been observed in Candida albicansand Listeria monocytogenes-infected macrophages, treated with P. sidoides root extracts [54]. Evidence for the immunomodulatory role of Pelargonium root extracts in the presence of intracellular residing mycobacteria was observed when gallic acid, methyl gallate, myricetin and isoquercetin, were identified as the constituents from P. reniforme roots responsible for increasing the killing activity of M. tuberculosis-infected macrophages [55]. It this study, we found that only methyl gallate (LE3 = 0.04) and myricetin $(\mathrm{LE} 3=0.03$ ) had ligand efficiency indices that were superior and equal to the AX20017 control efficiency, respectively. Interestingly, it was also previously observed that nicotiflorin, rutin and $p$-coumaric acid had immunomodulatory activity $[56,57]$. It remains to be seen if any of the compounds tested in this study exert an effect in M. tuberculosis-infected macrophages.

\section{Materials and Methods}

\subsection{Protein Preparation}

The three-dimensional crystal structure of the target $M t P k n G$ protein (PDB ID:2PZI), in complex with its ligand inhibitor (AX20017), was retrieved from the RCSB Protein Data Bank (http://www.pdb. org). The protein was used as a rigid structure and all water molecules and hetero-atoms were removed using BIOVIA Discovery Studio Visualizer v.4.5 (Accelrys). A PDBQT file of the target protein, with added polar hydrogen atoms, was subsequently prepared using AutoDock Tools v. 1.5.6rc3 [58].

\subsection{Ligand Preparation}

The ligands selected for docking were 84 natural products, previously isolated from the roots and the aerial parts of P. reniforme and P. sidoides [55,59-62]. All chemical structures were retrieved from SciFinder (https://scifinder.cas.org/scifinder/login). The structure of the ligand inhibitor (AX20017) 
was retrieved from its corresponding complex with $M t P k n G$ (PDB ID:2PZI), using BIOVIA Discovery Studio Visualizer v.4.5 (Accelrys). Each ligand structure was exported to ChemOffice v.16.0, and geometry-optimised using MM2 energy minimisation [63]. Docking files for all ligands were then prepared, using AutoDock Tools v. 1.5.6rc3 [58]. All rotatable bonds present were treated as non-rotatable, to perform rigid docking and minimise standard errors (typically of $2.85 \mathrm{kcal} / \mathrm{mol}$ ), likely due to ligands with many active rotatable bonds [64]. Gasteiger charges were assigned [65] and files were saved as PDBQT formats in preparation for docking.

\subsection{Binding Site Analysis and Prediction}

To analyse and identify the binding site and potential allosteric sites, SiteMap (Schrödinger, LLC, New York, NY, 2018) was utilised. This software employs van der Waals probes, in order to identify energetically favourable binding pockets. SiteMap was tasked to identify the five top-ranked possible receptor sites, using the default settings. The site score, druggability score and size were used to determine the most favourable receptor site [66,67].

\subsection{Grid Box Preparation and Docking Studies}

Parameters for the grid box, to define the size of the searching space around the $M t P k n G$ binding site residues, were prepared using AutoDock Tools v. 1.5.6rc3, while molecular docking simulations were executed with AutoDock Vina v. 1.1.2 [64]. The centre of the grid box was set to $x=19.234$, $y=-9.412, z=-3.495$. Its size was $22 \times 20 \times 20$ points in the $x, y$ and $z$ dimensions. The spacing was set at $1 \AA$. To validate the accuracy of the docking, and to allow a comparison between docking scores, the co-crystallised inhibitory ligand AX20017 was re-docked into MtPknG. Different orientations of the ligands were searched and ranked based on their energy scores. Upon visual inspection of all binding poses obtained, only poses with the lowest root mean square deviation (RMSD) value (threshold $<1.00 \AA$ ) were considered to provide a high accuracy of docking. The default values set in Autodock Vina were used as the parameters for the rigid ligand docking (exhaustiveness $=8$ ). The exhaustiveness was set to 16 for the flexible ligand docking. The docking scores were calculated as the predicted free energies of binding $(\Delta \mathrm{G}$ in $\mathrm{kcal} / \mathrm{mol})$. The lowest binding free energy-i.e., best score for the docking pose with the lowest (RMSD) —indicated the highest predictive ligand/protein affinity. Ligand efficiency indices were also calculated for all ligands as the free energy of binding/number of heavy atoms $(\mathrm{LE} 1=-\Delta \mathrm{G} / \mathrm{NHA})$, free energy of binding/number of carbons $(\mathrm{LE} 2=-\Delta \mathrm{G} / \mathrm{NoC})$, and free energy of binding/molecular weight (LE3 $=-\Delta \mathrm{G} / \mathrm{MW})$ [48] (Table S1).

\subsection{Protein-Ligand Interactions and Predictive Inhibition}

Specific intermolecular interactions between the best ligand docking poses and the binding site of $M t P k n G$ were further visualised using BIOVIA Discovery Studio Visualizer v.4.5 (Accelrys) (Table S2 and Figures 1 and 2).

\section{Conclusions}

A molecular docking approach was conducted to predict the binding affinity of 84 natural products present in the aerial parts and/or roots of Pelargonium reniforme and Pelargonium sidoides for the mycobacterial enzyme $M t P k n G$. A total of ten flavonoids showed high docking scores and, among them, compounds (4), (5) and (7) exhibited a $(-\Delta \mathrm{G} / \mathrm{MW})$ ligand efficiency index similar to the one obtained for the AX20017 control. A high ligand efficiency index was also observed for coumaric acid, coumaraldehyde, $p$-hydroxyphenyl acetic acid and $p$-hydroxybenzyl alcohol, methyl gallate and myricetin. Some of these compounds can be found in Pelargonium aerial parts, suggesting that the roots may not be the only plant part that could have anti-TB potential. In fact, the selection of Pelargonium roots over the aerial parts for use as an anti-TB remedy by traditional healers is customary, rather than intentional [68]. Further in vitro and in vivo studies are required to establish the effectiveness of these compounds in inhibiting $M t P k n G$ and in controlling TB. 
Supplementary Materials: Supplementary materials can be found at http:/www.mdpi.com/2223-7747/8/ 11/477/s1. Figure S1: Docked pose of nicotiflorin (3) in the MtPknG binding site showing molecular interactions-hydrogen-bonds as green dashed lines and hydrophobic bonds as pink/purple dashed lines-between (3) and $M t P k n G$, generated by BIOVIA Discovery Studio visualizer, Figure S2: Docked pose of orientin (4) in the MtPknG binding site showing molecular interactions-hydrogen-bonds as green dashed lines and hydrophobic bonds as pink/purple dashed lines-between (4) and MtPknG, generated by BIOVIA Discovery Studio visualizer, Figure S3: Docked pose of populnin (5) in the MtPknG binding site showing molecular interactions-hydrogen-bonds as green dashed lines and hydrophobic bonds as pink/purple dashed lines-between (5) and $M t P k n G$, generated by BIOVIA Discovery Studio visualizer, Table S1: Origin of Pelargonium natural products and their predicted free binding energy (docking score $\Delta \mathrm{G}$ in $\mathrm{kcal} / \mathrm{mol}$ ) and ligand efficiency indices towards MtPknG.

Author Contributions: Conceptualization, V.S., R.M.Q. and D.R.; methodology, V.S., R.M.Q. and C.B.O.; software, V.S., R.M.Q. and C.B.O.; validation, V.S., R.M.Q. and C.B.O.; formal analysis, V.S. and R.M.Q.; investigation, V.S., R.M.Q. and C.B.O.; resources, V.S.; data curation, V.S., R.M.Q. and C.B.O.; writing-original draft preparation, V.S. and R.M.Q.; writing-review and editing, V.S., R.M.Q., D.R., C.B.O. and N.L.; visualization, V.S., R.M.Q. and C.B.O.; supervision, V.S. and D.R.; project administration, V.S. and D.R.

Funding: This research received no external funding.

Acknowledgments: R.M.Q. acknowledges the Jordan University of Science and Technology for the award of a scholarship to pursue this research.

Conflicts of Interest: The authors declare no conflict of interest. The funders had no role in the design of the study; in the collection, analyses, or interpretation of data; in the writing of the manuscript, or in the decision to publish the results.

\section{References}

1. Daniel, T.M. The history of tuberculosis. Respir. Med. 2006, 100, 1862-1870. [CrossRef]

2. Global Tuberculosis Report 2018. World Health Organisation: Geneva, Switzerland, 2018. Available online: http://www.who.int/tb/publications/global_report/en/ (accessed on 1 May 2019).

3. Janssen, S.; Jayachandran, R.; Khathi, L.; Zinsstag, J.; Grobusch, M.P.; Pieters, J. Exploring prospects of novel drugs for tuberculosis. Drug Des. Dev. Ther. 2012, 6, 217-224.

4. Tiberi, S.; Muñoz-Torrico, M.; Duarte, R.; Dalcolmo, M.; D’Ambrosio, L.; Migliori, G.-B.; Zumla, A. New drugs and perspectives for new anti-tuberculosis regimens. Pulmonology 2018, 24, 86-98. [CrossRef]

5. Singh, V.; Mizrahi, V. Identification and validation of novel drug targets in Mycobacterium tuberculosis. Drug Discov. Today 2017, 22, 503-509. [CrossRef] [PubMed]

6. Lou, Z.; Zhang, X. Protein targets for structure-based anti-Mycobacterium tuberculosis drug discovery. Protein Cell 2010, 1, 435-442. [CrossRef]

7. Mdluli, K.; Kaneko, T.; Upton, A. Tuberculosis drug discovery and emerging targets. Ann. N. Y. Acad. Sci. 2014, 1323, 56-75. [CrossRef] [PubMed]

8. Baugh, L.; Phan, I.; Begley, D.W.; Clifton, M.C.; Armour, B.; Dranow, D.M.; Taylor, B.M.; Muruthi, M.M.; Abendroth, J.; Fairman, J.W.; et al. Increasing the structural coverage of tuberculosis drug targets. Tuberculosis 2015, 95, 142-148. [CrossRef] [PubMed]

9. Av-Gay, Y.; Everett, M. The eukaryotic-like Ser/Thr protein kinases of Mycobacterium tuberculosis. Trends Microbiol. 2000, 8, 238-244. [CrossRef]

10. Prisic, S.; Husson, R.N. Mycobacterium tuberculosis Serine/Threonine Protein Kinases. Microbiol. Spectr. 2014, 2, 681-708. [CrossRef] [PubMed]

11. Walburger, A.; Koul, A.; Ferrari, G.; Nguyen, L.; Prescianotto-Baschong, C.; Huygen, K.; Klebl, B.; Thompson, C.; Bacher, G.; Pieters, J. Protein Kinase G from Pathogenic Mycobacteria Promotes Survival Within Macrophages. Science 2004, 304, 1800-1804. [CrossRef]

12. Sundaramurthy, V.; Pieters, J. Interactions of pathogenic mycobacteria with host macrophages. Microbes Infect. 2007, 9, 1671-1679. [CrossRef] [PubMed]

13. Chao, J.; Wong, D.; Zheng, X.; Poirier, V.; Bach, H.; Hmama, Z.; Av-Gay, Y. Protein kinase and phosphatase signaling in Mycobacterium tuberculosis physiology and pathogenesis. Biochim. Biophys. Acta 2010, 1804, 620-627. [CrossRef] [PubMed]

14. Scherr, N.; Müller, P.; Perisa, D.; Combaluzier, B.; Jenö, P.; Pieters, J. Survival of Pathogenic Mycobacteria in Macrophages Is Mediated through Autophosphorylation of Protein Kinase G. J. Bacteriol. 2009, 191, 4546-4554. [CrossRef] [PubMed] 
15. Székely, R.; Waczek, F.; Szabadkai, I.; Németh, G.; Hegymegi-Barakonyi, B.; Erôs, D.; Szokol, B.; Pató, J.; Hafenbradl, D.; Satchell, J.; et al. A novel drug discovery concept for tuberculosis: Inhibition of bacterial and host cell signalling. Immunol. Lett. 2008, 116, 225-231. [CrossRef]

16. Kanehiro, Y.; Tomioka, H.; Pieters, J.; Tatano, Y.; Kim, H.; Iizasa, H.; Yoshiyama, H. Identification of Novel Mycobacterial Inhibitors Against Mycobacterial Protein Kinase, G. Front. Microbiol. 2018, 9, 1517. [CrossRef]

17. Wehenkel, A.; Bellinzoni, M.; Graña, M.; Duran, R.; Villarino, A.; Fernández, P.; André-Leroux, G.; England, P.; Takiff, H.; Cerveñansky, C.; et al. Mycobacterial Ser/Thr protein kinases and phosphatases: Physiological roles and therapeutic potential. Biochim. Biophys. Acta 2008, 1784, 193-202. [CrossRef]

18. Bellinzoni, M.; Wehenkel, A.M.; Durán, R.; Alzari, P.M. Novel mechanistic insights into physiological signaling pathways mediated by mycobacterial Ser/Thr protein kinases. Genes Immun. 2019, 20, 383-393. [CrossRef]

19. Caballero, J.; Morales-Bayuelo, A.; Navarro-Retamal, C. Mycobacterium tuberculosis serine/threonine protein kinases: Structural information for the design of their specific ATP-competitive inhibitors. J. Comput. Mol. Des. 2018, 32, 1315-1336. [CrossRef]

20. Gil, M.; Lima, A.; Rivera, B.; Rossello, J.; Urdániz, E.; Cascioferro, A.; Carrión, F.; Wehenkel, A.; Bellinzoni, M.; Batthyány, C.; et al. New substrates and interactors of the mycobacterial Serine/Threonine protein kinase PknG identified by a tailored interactomic approach. J. Proteom. 2019, 192, 321-333. [CrossRef]

21. Khan, M.Z.; Kaur, P.; Nandicoori, V.K. Targeting the messengers: Serine/threonine protein kinases as potential targets for antimycobacterial drug development. IUBMB Life 2018, 70, 889-904. [CrossRef]

22. Mori, M.; Sammartino, J.C.; Costantino, L.; Gelain, A.; Meneghetti, F.; Villa, S.; Chiarelli, L.R. An Overview on the Potential Antimycobacterial Agents Targeting Serine/Threonine Protein Kinases from Mycobacterium tuberculosis. Curr. Top. Med. Chem. 2019, 19, 646-661. [CrossRef] [PubMed]

23. Wolff, K.A.; De La Peña, A.H.; Nguyen, H.T.; Pham, T.H.; Amzel, L.M.; Gabelli, S.B.; Nguyen, L. A Redox Regulatory System Critical for Mycobacterial Survival in Macrophages and Biofilm Development. PLoS Pathog. 2015, 11, 1004839. [CrossRef] [PubMed]

24. Newman, D.J.; Cragg, G.M. Natural Products as Sources of New Drugs from 1981 to 2014. J. Nat. Prod. 2016, 79, 629-661. [CrossRef] [PubMed]

25. Sharifi-Rad, J.; Salehi, B.; Stojanović-Radić, Z.Z.; Fokou, P.V.T.; Sharifi-Rad, M.; Mahady, G.B.; Sharifi-Rad, M.; Masjedi, M.-R.; Lawal, T.O.; Ayatollahi, S.A.; et al. Medicinal plants used in the treatment of tuberculosisEthnobotanical and ethnopharmacological approaches. Biotechnol. Adv. 2017. [CrossRef]

26. Gautam, R.; Saklani, A.; Jachak, S.M. Indian medicinal plants as a source of antimycobacterial agents. J. Ethnopharmacol. 2007, 110, 200-234. [CrossRef]

27. Newton, S.M.; Lau, C.; Gurcha, S.S.; Besra, G.S.; Wright, C.W. The evaluation of forty-three plant species for in vitro antimycobacterial activities; isolation of active constituents from Psoralea corylifolia and Sanguinaria canadensis. J. Ethnopharmacol. 2002, 79, 57-67. [CrossRef]

28. Salomon, C.E.; Schmidt, L.E. Natural products as leads for tuberculosis drug development. Curr. Top. Med. Chem. 2012, 12, 735-765. [CrossRef]

29. Guzman, J.D.; Gupta, A.; Bucar, F.; Gibbons, S.; Bhakta, S. Antimycobacterials from natural sources: Ancient times, antibiotic era and novel scaffolds. Front. Biosci. 2012, 17, 1861-1881. [CrossRef]

30. Dashti, Y.; Grkovic, T.; Quinn, R.J. Predicting natural product value, an exploration of anti-TB drug space. Nat. Prod. Rep. 2014, 31, 990-998. [CrossRef]

31. Santhosh, R.S.; Suriyanarayanan, B. Plants: A source for new antimycobacterial drugs. Planta Med. 2014, 80, 9-21. [CrossRef]

32. Chinsembu, K.C. Tuberculosis and nature's pharmacy of putative anti-tuberculosis agents. Acta Trop. 2016, 153, 46-56. [CrossRef] [PubMed]

33. Kolodziej, H. Traditionally used Pelargonium species: Chemistry and biological activity of umckaloabo extracts and their constituents. Curr. Top. Phytochem. 2000, 3, 77-93.

34. Bladt, S.; Wagner, H. From the Zulu medicine to the European phytomedicine Umckaloabo ${ }^{\circledR}$. Phytomedicine 2007, 14, 2-4. [CrossRef] [PubMed]

35. Helmstädter, A. Umckaloabo-Late vindication of a secret remedy. Pharm. Historian 1996, 26, $2-4$.

36. Newsom, S. Stevens' cure: A secret remedy. J. R. Soc. Med. 2002, 95, 463-467.

37. Sechehaye, A. The Treatment of Tuberculosis with Umckaloabo (Stevens' Cure); B. Fraser \& Co.: London, UK, 1930. 
38. An English Physician. Tuberculosis, Its Treatment and Cure with the Help of Umckaloabo (Stevens); B. Fraser \& Co.: London, UK, 1931.

39. Brendler, T.; Van Wyk, B.-E. A historical, scientific and commercial perspective on the medicinal use of Pelargonium sidoides (Geraniaceae). J. Ethnopharmacol. 2008, 119, 420-433. [CrossRef] [PubMed]

40. Meng, X.-Y.; Zhang, H.-X.; Mezei, M.; Cui, M. Molecular docking: A powerful approach for structure-based drug discovery. Curr. Comput. Drug Des. 2011, 7, 146-157. [CrossRef]

41. Sundarrajan, S.; Lulu, S.; Arumugam, M. Computational evaluation of phytocompounds for combating drug resistant tuberculosis by multi-targeted therapy. J. Mol. Model. 2015, 21, 247. [CrossRef]

42. Appunni, S.; Rajisha, P.; Rubens, M.; Chandana, S.; Singh, H.N.; Swarup, V. Targeting PknB, an eukaryotic-like serine/threonine protein kinase of Mycobacterium tuberculosis with phytomolecules. Comput. Boil. Chem. 2017, 67, 200-204. [CrossRef]

43. Scherr, N.; Honnappa, S.; Kunz, G.; Mueller, P.; Jayachandran, R.; Winkler, F.; Pieters, J.; Steinmetz, M.O. Structural basis for the specific inhibition of protein kinase $G$, a virulence factor of Mycobacterium tuberculosis. Proc. Natl. Acad. Sci. USA 2007, 104, 12151-12156. [CrossRef]

44. Tiwari, D.; Singh, R.K.; Goswami, K.; Verma, S.K.; Prakash, B.; Nandicoori, V.K. Key Residues in Mycobacterium tuberculosis Protein Kinase G Play a Role in Regulating Kinase Activity and Survival in the Host*. J. Boil. Chem. 2009, 284, 27467-27479. [CrossRef] [PubMed]

45. Singh, N.; Tiwari, S.; Srivastava, K.K.; Siddiqi, M.I. Identification of Novel Inhibitors of Mycobacterium tuberculosis PknG Using Pharmacophore Based Virtual Screening, Docking, Molecular Dynamics Simulation, and Their Biological Evaluation. J. Chem. Inf. Model. 2015, 55, 1120-1129. [CrossRef] [PubMed]

46. Santhi, N.; Aishwarya, S. Insights from the molecular docking of withanolide derivatives to the target protein PknG from Mycobacterium tuberculosis. Bioinformation 2011, 7, 1-4. [CrossRef] [PubMed]

47. Chen, D.; Ma, S.; He, L.; Yuan, P.; She, Z.; Lu, Y. Sclerotiorin inhibits protein kinase G from Mycobacterium tuberculosis and impairs mycobacterial growth in macrophages. Tuberculosis 2017, 103, 37-43. [CrossRef] [PubMed]

48. García-Sosa, A.T.; Hetényi, C.; Maran, U. Drug efficiency indices for improvement of molecular docking scoring functions. J. Comput. Chem. 2010, 31, 174-184. [CrossRef] [PubMed]

49. Kayser, O.; Kolodziej, H. Antibacterial Activity of Extracts and Constituents of Pelargonium sidoides and Pelargonium reniforme. Planta Med. 1997, 63, 508-510. [CrossRef] [PubMed]

50. Mativandlela, S.; Meyer, J.; Hussein, A.; Lall, N. Antitubercular Activity of Compounds Isolated from Pelargonium sidoides. Pharm. Biol. 2007, 45, 645-650. [CrossRef]

51. Seidel, V.; Taylor, P.W. In vitro activity of extracts and constituents of Pelagonium against rapidly growing mycobacteria. Int. J. Antimicrob. Agents 2004, 23, 613-619. [CrossRef]

52. Kayser, O.; Kolodziej, H.; Kiderlen, A.F. Immunomodulatory principles of Pelargonium sidoides. Phytother. Res. 2001, 15, 122-126. [CrossRef]

53. Koch, E.; Lanzendorfer-Goossens, H.; Whon, C. Stimulation of interferon (INF)-b-synthesis and natural killer (NK) cell activity by an aqueous-ethanolic extract from roots of Pelargonium sidoides (Umckaloabo ${ }^{\circledR}$ ). Arch. Pharmacol. 2002, 365 (Suppl. 1), 288.

54. Kolodziej, H. Antimicrobial, Antiviral and Immunomodulatory Activity Studies of Pelargonium sidoides $(\operatorname{EPs}((\mathrm{R})) 7630)$ in the Context of Health Promotion. Pharmaceuticals 2011, 4, 1295-1314. [CrossRef] [PubMed]

55. Kim, C.; Griffiths, W.; Taylor, P.; Griffiths, W. Components derived fromPelargoniumstimulate macrophage killing of Mycobacteriumspecies. J. Appl. Microbiol. 2009, 106, 1184-1193. [CrossRef] [PubMed]

56. Akbay, P.; Başaran, A.A.; Ündeger, Ü.; Başaran, N.; Akbay, P. In vitro immunomodulatory activity of flavonoid glycosides from Urtica dioica L. Phytother. Res. 2003, 17, 34-37. [CrossRef] [PubMed]

57. Pragasam, S.J.; Venkatesan, V.; Rasool, M. Immunomodulatory and anti-inflammatory effect of p-coumaric acid, a common dietary polyphenol on experimental inflammation in rats. Inflammation 2013, 36, 169-176. [CrossRef] [PubMed]

58. Morris, G.M.; Huey, R.; Lindstrom, W.; Sanner, M.F.; Belew, R.K.; Goodsell, D.S.; Olson, A.J. AutoDock4 and AutoDockTools4: Automated docking with selective receptor flexibility. J. Comput. Chem. 2009, 30, 2785-2791. [CrossRef] [PubMed]

59. Latté, K.P.; Ferreira, D.; Venkatraman, M.S.; Kolodziej, H. O-Galloyl-C-glycosylflavones from Pelargonium reniforme. Phytochemistry 2002, 59, 419-424. [CrossRef] 
60. Latté, K.P.; Kaloga, M.; Schäfer, A.; Kolodziej, H. An ellagitannin, n-butyl gallate, two aryltetralin lignans, and an unprecedented diterpene ester from Pelargonium reniforme. Phytochemistry 2008, 69, 820-826. [CrossRef]

61. Hauer, H.; Germer, S.; Elsasser, J.; Ritter, T. Benzopyranones and their sulfate esters from Pelargonium sidoides. Planta Med. 2010, 76, 350-352. [CrossRef]

62. Kolodziej, H. Fascinating metabolic pools of Pelargonium sidoides and Pelargonium reniforme, traditional and phytomedicinal sources of the herbal medicine Umckaloabo ${ }^{\circledR}$. Phytomedicine 2007, 14, 9-17. [CrossRef]

63. Allinger, N.L. Conformational analysis. 130. MM2. A hydrocarbon force field utilizing V1 and V2 torsional terms. J. Am. Chem. Soc. 1977, 99, 8127-8134. [CrossRef]

64. Trott, O.; Olson, A.J. AutoDock Vina: Improving the speed and accuracy of docking with a new scoring function, efficient optimization, and multithreading. J. Comput. Chem. 2010, 31, 455-461. [CrossRef]

65. Gasteiger, J.; Marsili, M. Iterative partial equalization of orbital electronegativity-A rapid access to atomic charges. Tetrahedron 1980, 36, 3219-3228. [CrossRef]

66. Halgren, T. New Method for Fast and Accurate Binding-site Identification and Analysis. Chem. Boil. Drug Des. 2007, 69, 146-148. [CrossRef] [PubMed]

67. Halgren, T.A. Identifying and Characterizing Binding Sites and Assessing Druggability. J. Chem. Inf. Model. 2009, 49, 377-389. [CrossRef] [PubMed]

68. Lewu, F.; Grierson, D.; Afolayan, A.; Lewu, F. The leaves of Pelargonium sidoides may substitute for its roots in the treatment of bacterial infections. Boil. Conserv. 2006, 128, 582-584. [CrossRef]

(C) 2019 by the authors. Licensee MDPI, Basel, Switzerland. This article is an open access article distributed under the terms and conditions of the Creative Commons Attribution (CC BY) license (http://creativecommons.org/licenses/by/4.0/). 